Gi respons på artikler gjennom artiklenes kommentarfelt på tidsskriftet.no.

Innleggene publiseres fortløpende på Tidsskriftets nettside og et utvalg

av innleggene publiseres også i papirutgaven i spalten «Brev til redaktøren».

Redaksjonen forbeholder seg retten til å foreta redaksjonelle endringer.

Forfattere av vitenskapelige artikler har tilsvarsrett, jf. Vancouver-gruppens regler.

\section{Re: Legers private henvisningspraksis}

Artikkelen Legers private henvisningspraksis presenteres i sjangeren Medisinsk etikk og fremstår som en uttalelse fra Rådet for legeetikk (1). Da må det tas på alvor, og en kommentar er påkrevet.

Innføringen av fastlegeordningen har nesten umerkelig medført en glidning mot den oppfatning at all primær legevirksomhet egentlig bør ivaretas av fastleger. Dette er nok fra enkelte hold, med påberopelse av «prinsipielle» grunner, også ansett som en ønskelig utvikling.

Imidlertid finnes det fremdeles leger utenfor fastlegesystemet. Jeg tenker ikke her på fulltidsarbeidende leger ved private legesentre. Ingen trekker vel i tvil deres naturlige plass i primærhelsetjenesten. Men det finnes også andre. Sykehusleger og leger i administrative fulltidsstillinger kan ha en begrenset privatpraksis. Pensjonerte leger kan ha litt praksis overfor «gamle» pasienter. Og så hender det jo at egen familie og bekjente - og for den saks skyld en selv - kan trenge en hjelpende hånd.

Jeg medgir at det har forekommet at jeg, uten å være fastlege, har benyttet meg av min rett som lege til å henvise til ulike spesialisthelsetjenester når indikasjon forelå, både i den tid jeg selv var $i$ arbeid som sykehuslege, og senere som pensjonist, noe som jeg oppfatter at Hytten betegner som at jeg har «utnyttet min posisjon». Jeg har endog i enkelte tilfeller henvist meg selv eller en av mine nærmeste. Men jeg har her, som ellers i min legevirksomhet, fulgt etikkreglene med skriftlige henvisninger mv., og har selvfølgelig også respektert mottakers prioriteringer og ventet på tur når det var ventetid.

Det er heller ikke utenkelig at man i enkelte tilfeller kan gjøre litt nytte for seg med en «second opinion» overfor pasienter som av en eller annen grunn er kommet diagnostisk eller terapeutisk litt skjevt ut hos sin fastlege - det forekommer en gang iblant.

Selvfølgelig kan leger i noen tilfeller ha benyttet sin posisjon til å finne snarveier og «snike i køen» for seg selv eller sine pasienter. Dette skal man slå ned på, og ansvaret ligger særlig på dem som mottar og vurderer henvisningene. Men man bør ikke for dette formål forsøke å mistenkeliggjøre enhver praksis fra leger utenfor «systemet».

Jeg tar bestemt avstand fra Etikkrådets insinuasjoner om at undertegnedes og andre kollegers privatpraksis innebærer å «høste uberettiget fordel i helsevesenet med risiko for bruk av overflødige og kostbare metoder» (1). Det tilligger ikke Etikkrådet å uttale seg om hvilke leger som ikke kan eller bør behandle og eventuelt henvise pasienter. Dette reguleres ikke i etikkreglene, men i lov og regelverk.

Jeg mener at Etikkrådet i dette tilfellet har gått ut over sitt mandat og sin kompetanse.

\section{Torbjørn Pihl}

fam.pihl@frisurf.no

Torbjørn Pihl (f. 1940) er pensjonert sykehuslege.

Ingen oppgitte interessekonflikter

Litteratur

1. Hytten K. Legers private henvisningspraksis. Tidsskr Nor Legeforen 2014 $134: 435$

\section{K. Hytten svarer:}

Kollega Pihl synes å mene at Rådet for legeetikk insinuerer at han (og andre) har utnyttet sin posisjon når han har henvist pasienter til spesialisthelsetjenesten. Det mener vi ikke. Selv om de fleste i landet nå er knyttet til en fastlege, er Rådet kjent med at det også er en del leger som driver en liten privatpraksis ved siden av sin hovedstilling eller etter pensjonering. Det er også leger som driver allmennlegepraksis på fulltid uten å være fastleger.

At leger som Pihl med en liten praksis også kan og bør henvise til spesialisthelsetjenesten tar Rådet høyde for i det nest siste avsnittet av artikkelen Legers private henvisningspraksis (1): «Samtidig erkjenner Rådet at det finnes medisinsk begrunnede situasjoner som gjør direkte henvendelse til sykehus riktig og nødvendig. Det kan også gjelde elektive situasjoner der det er åpenbart at ytterligere diagnostikk og behandling må skje i spesialisthelsetjenesten. I slike situasjoner kan direkte henvisninger være ressursbesparende, jfr Etiske regler for leger Kap I §12 .»

\section{Karsten Hytten}

karsten@hytten.no

Karsten Hytten (f. 1953) er dr. med. og psykiater. Han er nestleder i Rådet for legeetikk.

Ingen oppgitte interessekonflikter.

Litteratur

1. Hytten K. Legers private henvisningspraksis. Tidsskr Nor Legeforen 2014 134: 435.

\section{Re: Kvinne i 30-årene med kronisk utmattelse}

Selv om Bjartveit og medarbeidere i sin artikkel er kritisk til diagnosen og behandlingen denne kvinnen har mottatt av en privat klinikk, og positiv til behandlingen i psykiatrien, så setter de søkelyset på den mangelfulle kompetansen om diagnostikk og behandling for syke mennesker med kronisk utmattelsessyndrom og andre diffuse diagnoser (1).

Som en motvekt til eksemplet i denne artikkelen, kunne jeg nevne mange eksempler på feildiagnoser som har endt med alvorlig feilbehandling i psykiatrien, og psykiaternes «kamp» om eierskapet til denne utsatte og stigmatiserte pasientgruppen. Jeg vil heller støtte opp om artikkelens konklusjon om at denne pasientgruppen er en utfordring for dagens helsevesen.

Vi trenger et norsk senter bygd opp fra grunnen av leger og biologer som er genuint interessert $\mathrm{i}$ å finne årsakene til lidelser som seiler under betegnelser som kronisk utmattelsessyndrom og ME. I dag har vi mangelfulle analyser og manglende kompetanse på å tolke analysene for å stille riktig diagnose. Motstanden mot langvarig antibiotikabruk for å få bukt med infeksjoner som kan ligge til grunn for lidelsene, mener jeg baserer seg på frykt fremfor forskningsbasert viten. Samtidig som det stilles krav om forskningsbasert viten for å godkjenne langvarig bruk av antibiotika, blir private klinikker som jobber med dette, motarbeidet. Hvor er logikken? Imens lider pasientene. Mitt håp er at helsemyndighetene oppretter et kompetansesenter for diagnostikk og behandling med ansatte som ikke er innelåst i en profesjonsboble, eller som har en annen agenda enn å hjelpe pasientene. 
I dag er pasientene sine egne og hverandres «leger», og useriøse, alternative behandlere har et godt marked. Jeg savner at flere leger og psykiatere står frem og tar et oppgjør med helsemyndighetenes mangelfulle satsing på denne pasientgruppen, og med de leger som med sine utspill er bidragsytere til det samme. Vi som har levd noen år, vet etter hvert at skråsikkerheten er kunnskapens verste fiende.

\author{
Jan Nystrøm \\ jan.nystrøm@getmail.no \\ Jan Nystrøm (f. 1944) er pensjonist. \\ Ingen oppgitte interessekonflikter. \\ Litteratur \\ 1. Bjartveit $\mathrm{K}$, Helskog EH, Kryvi PD et al. Kvinne i 30-årene med kronisk utmat- \\ telse. Tidsskr Nor Legeforen 2014; 134: 423-5.
}

\section{E.H. Helskog og medarbeider svarer:}

Takk for respons. Vårt hovedbudskap er at årsaksforhold, diagnosekriterier og behandling med dokumentert effekt for denne pasientgruppen er uavklart og mangelfull. Kompetansesenteret som etterlyses, ble opprettet i 2012 - Nasjonal kompetansetjeneste for CFS/ ME ved Oslo universitetssykehus, men vi opplever at de norske retningslinjene som finnes, gir liten støtte i den kliniske hverdagen $(1,2)$.

For å unngå at pasienter havner under feil behandlingsopplegg, er det viktig å sørge for at en psykiatrisk anamnese foreligger før diagnosen $\mathrm{CFS} / \mathrm{ME}$ vurderes. Feil diagnose kan få alvorlige konsekvenser - behandlingsintervensjonene for utmattelse og depresjon er nærmest motsatt.

Diagnostisering og behandling av pasienter med diffuse symptombilder krever at man ekskluderer en rekke lidelser. Vi mener det er svært uheldig dersom CFS/ME-diagnosen etableres for tidlig.

Vi tillater oss å spekulere litt rundt hvorvidt de ulike behandlingsoppleggene, herunder langvarige antibiotikakurer, og en del alternative intervensjoner som det finnes lite eller ingen dokumentasjon på, har effekt. Private aktører kan i dag sette utmattelsesdiagnoser uten å utelukke andre lidelser med tilsvarende symptombilder, og igangsette langvarige og kostbare behandlinger på til tider sviktende eller mangelfullt grunnlag.

\section{Espen Hauk Helskog \\ espenhauk@hotmail.com \\ Kristin Bjartveit}

Espen Hauk Helskog (f. 1977) er psykolog ved Nedre Romerike DPS, Akershus universitetssykehus.

Ingen oppgitte interessekonflikter

Kristin Bjartveit (f. 1957) er spesialist i psykiatri og overlege ved Psykiatrisk avdeling, Sørlandet sykehus, Arendal.

Ingen oppgitte interessekonflikter

\section{Litteratur}

1. Helsedirektoratet Nasjonal veileder. Pasienter med CFS/ME: Utredning, diagnostikk, behandling, rehabilitering, pleie og omsorg. Oslo: Helsedirektoratet, 2013.

2. Oslo universitetssykehus, ME/CFS-Senter. Veileder i forbindelse med utredning av pasienter der man mistenker Myalgisk encephalopati (ME)/Kronisk utmattelsessyndrom (CFS) i allmennpraksis. www.oslo-universitetssykehus.no/ SiteCollectionDocuments/Om\%20oss/Avdelinger/Medisinsk\%20klinikk/ ME-CFS/ME-utredning\%20allm\%20lege\%20 nov\%2011.pdf (7.3.2014).

\section{Re: Kiropraktorutdanning i Norge nå!}

Som studieleder ved en av landets utdanninger av fysioterapeuter kan jeg ikke la være å reagere på påstanden om at «dokumentasjonen av fysioterapi er enda dårligere enn kiropraktikk» $\mathrm{i}$ artikkelen til Stein Evensen (1). Det er en påstand helt uten rot i virkeligheten! Dette er en viktig fagdiskusjon hvor jeg forventer at seriøse deltakere forsøker å sette seg inn i realitetene.
Kronikken har mange interessante sider, og det er viktig at det settes krav til dokumentasjon i det fremtidige Helse-Norge. Fysioterapi har hatt en formidabel vekst i kunnskapsbasert dokumentasjon de siste tiårene, herunder massiv forskning. Det vil et PubMedsøk enkelt bevise. Forskning og dokumentasjon har også bidratt til en endring i praksis, selv om mye gjenstår.

\section{Håvard Østerås \\ Havard.osteras@hist.no}

Håvard Østerås (f. 1971) er studieleder ved Høgskolen i Sør-Trøndelag. Ingen oppgitte interessekonflikter.

Litteratur

1. Evensen S. Kiropraktorutdanning i Norge nå! Tidsskr Nor Legeforen - Publisert først på nett 4. mars 2014 doi: 10.4045/tidsskr.14.0121.

\section{Re: Kiropraktorutdanning i Norge nå!}

Det er hyggelig at en av de mest reflekterte artiklene om kiropraktikk i norske medier i nyere tid kommer fra en forfatter med medisinsk bakgrunn (1). Det er sjelden å se en akademisk fagperson som er så fri for gamle fordommer og utslitte kritiske argumenter.

Jeg gir min fulle tilslutning til Evensen om at det ikke er mangel på forskningsinitiativ i det kiropraktiske miljøet som er problemet, men manglende økonomisk og politisk vilje til å følge opp disse positive initiativene. Norge har store utfordringer når det gjelder sykefravær og redusert arbeidsevne som følge av muskel- og skjelettrelaterte problemer. Her trengs en meget bevisst politisk handlekraft, som støttes av økonomiske bevilgninger til forskning og utdanning.

\section{Ole Christian Kvammen}

olekiro@live.no

Ole Christian Kvammen (f. 1970) er kiropraktor ved Fokus Helse

\& Trening, Sandefjord.

Ingen oppgitte interessekonflikter.

\section{Litteratur}

1. Evensen S. Kiropraktorutdanning i Norge nå! Tidsskr Nor Legeforen - Publisert først på nett 4. mars 2014 doi: 10.4045/tidsskr.14.0121

\section{S. Evensen svarer:}

Håvard Østerås kritiserer meg for å ha påstått at «dokumentasjonen av fysioterapi er enda dårligere enn kiropraktikk». Det er pussig å bli kritisert for noe jeg ikke har skrevet. I min artikkel står det: «Det er ikke lite av dagens medisinske praksis som fortsatt mangler dokumentasjon. Innen fysioterapi står det sannsynligvis enda dårligere til.» Det er fra min side ment som kritikk av egen praksis, en kritikk som også rammer fysioterapi. Østerås har tolket dette feil og deretter vridd det til et sitat oppfunnet av ham selv. Å tillegge meg et slikt sitat, synes jeg er kritikkverdig.

En kortversjon av min mening om dokumentasjonen innen fysioterapi er at effekten og nytten av fysioterapi i forbindelse med preog postoperative tilstander er meget godt dokumentert, men samtidig er det et problem at en rekke av de metodene fysioterapeuter anvender, er dårlig dokumentert. Der dokumentasjon foreligger, vises ofte bare kortvarig effekt. Det gjelder ikke minst ved fysikalskmedisinsk opptrening knyttet til kroniske tilstander. Her forsvinner effekten ofte i løpet av kort tid etter at treningsperioden er avsluttet. Mange av de millioner kroner som refunderes fysioterapeuter på diverse private institutter etter henvisning fra lege, er ressurser som med fordel kunne vært benyttet bedre andre steder i helsevesenet.

\section{Stein Evensen}

s.a.evensen@medisin.uio.no

Stein Evensen (f. 1942) er professor emeritus.

Ingen oppgitte interessekonflikter. 